\title{
PENGARUH LAMA PENYIMPANAN DAN KONDISI DAM TERHADAP KADAR ZAT ORGANIK AIR MINUM DI WILAYAH KERJA PUSKESMAS 1 CILONGOK TAHUN 2016
}

\author{
Dzuriyanis Sa'adah $^{1)}$, Suparmin ${ }^{2)}$, Teguh Widiyanto ${ }^{3)}$ \\ Jurusan Kesehatan Lingkungan, Politeknik Kesehatan Kemenkes Semarang, \\ Jl.Raya Baturaden KM 12 Purwokerto, Indonesia
}

\begin{abstract}
Abstrak
Air minum merupakan air yang diolah melalui beberapa proses. Semakin lama penyimpanan memnungkinkan adanya pertumbuhan mikroorganisme dan menyebabkan kadar zat organik meningkat yang dapat menyebabkan timbulnya bau, berubahnya rasa dan gangguan kesehatan. Tujuan penelitian yaitu mengetahui pengaruh lama penyimpanan dan kondisi DAM terhadap kadar zat organik air minum. Metode penelitian adalah penelitian observasional dengan desain cross sectional. Hasil penelitian menunjukkan bahwa rata-rata kadar zat organik air minum yang disimpan 0 sampai 4 hari pada kondisi DAM yañg berbeda berturut-turut adalah DAM MS $=7,96 \mathrm{mg} / \mathrm{l} ; 28,1 \mathrm{mg} / \mathrm{l} ; 12, \overline{\mathrm{mg}} / \mathrm{l}$. DAM TMS = 12,8 mg/l;24,03 mg/l;10,5 mg/l. Hasil analisis lama penyimpanan dengan kadar zat organik menunjukan nilai $p=0,000$ berarti $p<0,05$ maka Ho ditolak, sedangkan kondisi DAM yang memenuhi syarat dan tidak memenuhi syarat dengan kadar zat organik nilai $p=0,727$ berarti $p>0,05$ maka Ho diterima. Disimpulkan ada perbedaan kadar zat organik air minum dengan lama penyimpanan (0 hari,2 hari, 4 hari) serta tidak ada perbedaan kadar zat organik air minum pada kondisi DAM (memenuhi syarat dan tidak memenuhi syarat). Disarankan untuk masyarakat sebaiknya mengkonsumsi air minum sebelum $2 \times 24$ jam sejak pengisian, pengusaha DAM selalu menjaga kualitas air minum yang dijual dan perlu dilakukan penelitian dengan penyimpanan yang lebih lama.
\end{abstract}

Kata kunci Kadar Zat Organik, Kondisi DAM, Lama Penyimpanan

\begin{abstract}
The Effect of Storage Length and DAM Condition Towards Organic Subtances Content Of Drinking Water in Puskesmas Working Area 1 Cilongok Year 2016. Drinking water is water treated through several processes. The longer storage allows for the growth microorganism and lead increase levels of organic substance that cause odor, taste changing and health problems. The purpose of this research is to find out the the effect of storage time and DAM condition towards the organic substances content of drinking water. The method used in this research is observation with cross sectional design. The result of the research shows the average levels organic substances drinking water storage 0 to 4 days at Dam different conditions are DAM MS=7,96 mg/l;28,1 mg/l;12,2 $\mathrm{mg} / \mathrm{l} . \mathrm{DAM} T \mathrm{TMS}=12,8 \mathrm{mg} / \mathrm{l} ; 24,03 \mathrm{mg} / \mathrm{l} ; 10,5 \mathrm{mg} / \mathrm{l}$. The results of the analysis of storage time length with high levels organic substances shows the mean value of $p=0,000, p<0,05$ then Ho is rejected, while the condition of DAM qualified and not qualified with high levels of organic substances means value of $p=0,727, p>0,05$ then Ho is accepted. It is concluced that differences between organic substance levels with storage time length ( 0 day,2 days,4days) and no differences in the levels of organic substances in drinking water in DAM conditions (qualified and not qualified). People are suggested to consume dringking water before $2 \times 24$ hours since the filling, Dam keeper always maintain the quality of drinking water dan it is necessary to conduct further research with longer time.
\end{abstract}

Keywords: Organic Subtances Content, DAM Condition, Storage Length

\section{PENDAHULUAN}

HL. Bloom (Notoatmodjo, 2007) menjelaskan bahwa ada 4 faktor yang mempengaruhi kesehatan, baik kesehatan individu maupun kesehatan masyarakat yaitu perilaku, pelayanan kesehatan, keturunan dan lingkungan. Faktor lingkungan berpengaruh paling besar, untuk mencapai lingkungan yang sehat didalamnya terdapat upaya penyehatan air.

1) Email : dzuriyanis@gmail.com

2) Email : pakparmin@yahoo.com

3) Email : teguhwidiyanto007@gmail.com
Air minum merupakan air yang diolah melalui beberapa proses. Semakin lama penyimpanan memungkinkan adanya pertumbuhan mikroorganisme dan menyebabkan kadar zat organik meningkat yang dapat menyebabkan timbulnya bau, berubahnya rasa dan gangguan kesehatan (Ana Hidayati,2010).

Zat organik sebagai angka permanganate dalam air minum maksimal $10 \mathrm{mg} / \mathrm{l}$ (Permenkes No 492 Tahun 2010). Makin tinggi kandungan zat organik 
dalam air maka air tersebut telah tercemar. Pertumbuhan zat organik juga mempengaruhi tumbuhnya mikroorganisme yang dipengaruhi juga oleh temperature, $\mathrm{pH}$, kelembaban ruangan dan keadaan sanitasi.

Tujuan penelitian yaitu mengetahui pengaruh lama penyimpanan dan kondisi DAM terhadap kadar zat organik air minum di wilayah kerja Puskesmas 1 CilongokTahun 2016.

\section{BAHAN DAN METODE}

Jenis penelitian adalah penelitian observasional menggunakan desain cross sectional, yaitu menganalisa ciri populasi pada suatu waktu tertentu. Populasi adalah seluruh Depot Air Minum di wilayah kerja Puskesmas 1 Cilongok. Sampel pada penelitian ini adalah 2 Depot Air Minum, 1 DAM yang memenuhi syarat mikrobiologis dan hygiene sanitasi serta 1 DAM yang tidak memenuhi syarat mikrobiologis dan hygiene sanitasi.

Cara pengumpulan data yaitu berupa:

1. Dokumentasi yaitu untuk mendapatkan data sekunder berupa data umum mengenai kondisi Depot Air Minum di wilayah kerja Puskesmas 1 Cilongok

2. Perhitungan lama penyimpanan air minum yaitu 0 hari, 2 hari dan 4 hari

3. Pemeriksaan kadar zat organik dengan lama penyimpanan (0 hari, 2 hari dan 4 hari) pada kondisi DAM memenuhi syarat dan tidak memenuhi syarat di Laboratorium Masyarakat Kabupaten Purbalingga

Hasil pemeriksaan dianalisis menggunakan soft ware analisis data yang terdiri dari analisis univariate untuk menggambarkan tiap variabel dan analisis bivariate menggunakan uji Anova Factorial.

\section{HASIL DAN PEMBAHASAN}

Univariate

Kadar Zat Organik Air Minum dengan Lama Penyimpanan (0 hari, 2hari dan 4 hari) pada kondisi DAM MS dan TMS

Tabel 3.1 Kadar Zat Organik Air Minum

\begin{tabular}{ccc}
\hline Kondisi DAM & $\begin{array}{c}\text { Lama } \\
\text { Penyimpanan }\end{array}$ & $\begin{array}{c}\text { Mean } \\
\mathbf{( M g} / \mathbf{l})\end{array}$ \\
\hline \multirow{2}{*}{ Memenuhi } & 0 Hari & 7.9667 \\
Syarat & 2 Hari & 28.1000 \\
& 4 Hari & 12.2000 \\
& Total & 16.0889 \\
Tidak & 0 Hari & 12.800 \\
Memenuhi & 2 Hari & 24.0333 \\
Syarat & 4 hari & 10.5667 \\
& Total & 15.8000 \\
\hline
\end{tabular}

Hasil pemeriksaan kadar zat organik jika dilihat dari rata-rata kadar zat organik seperti yang ditunjukan oleh Tabel 3.1 menurut lama penyimpanan, kadar zat organik 0 hari sampai penyimpanan 2 hari kadarnya mengalami kenaikan, akan tetapi setelah penyimpanan 4 hari mengalami penurunan. Rata -rata kadar zat organik pada 0 Hari adalah 10,38 mg/l, pada 2 hari adalah 26,06 mg/l dan setelah penyimpanan 4 hari adalah 11,38 mg/l.

1. Lama penyimpanan 0 Hari

Rata-rata kadar zat organik air minum DAM TMS dengan lama penyimpanan 0 hari berarti lebih tinggi dibandingkan dengan rata-rata kadar zat organik air minum DAM MS dengan lama penyimpanan 0 hari.

Hal ini dimungkinkan karena kondisi DAM TMS (Tidak Memenuhi Syarat) tempat pengolahan air minum dalam kondisi terbuka (tidak tertutup kaca atau tidak menggunakan pintu yang tertutup rapat) dan saat pengisian air minum ke galon langsung dari kran pengolah (tidak hygienis) sehingga dapat terjadi pencemaran zat organik yang lebih tinggi.

Tempat pengisian harus didesain hanya untuk maksud pengisian produk jadi dan harus menggunakan pintu yang dapat menutup rapat (Kepmenperindag RI No 651/2004).

Lama penyimpanan 0 hari pada kondisi DAM MS masih memenuhi syarat kadar zat organik air minum. Hal ini dapat dimungkinkan karena secara alami kadar zat organik ada dalam air minum namun dapat dikurangi atau dihilangkan dengan menggunakan filter karbon aktif. Menurut Nusa Idaman Said (2011) menyatakan bahwa filter karbon aktif dapat menghilangkan atau mengurangi bau, warna, rasa dan bahan organik. Yang berarti pada kondisi DAM MS proses pengolahan filter karbon aktif masih efektif untuk menurunkan kadar zat organik atau mengolah air baku.

2. Lama Penyimpanan 2 Hari

Pada lama penyimpanan 2 hari baik pada DAM MS maupun DAM TMS rata-rata kadar zat organiknya mengalami kenaikan dibandingkan lama penyimpanan 0 hari.

Kenaikan zat organik air minum ini dimungkinkan dapat dipengaruhi oleh perkembangbiakan mikroorganisme dan kesalahan peneliti dalam pengambilan sampel dimana peneliti tidak melakukan pengambilan sampel secara steeril serta wadah yang digunakan untuk pengambilan sampel tidak hygienis dan steeril sehingga dapat mempengaruhi dan meningkatkan kadar zat organik dalam air minum yang diperiksa.

Air minum tidak bisa dikonsumsi lebih dari 24 jam karena bakteri atau mikroorganisme mulai mengalami perkembangbiakkan setelah 24 jam sejak air minum diisikan ke dalam botol atau gallon yang dikhawatirkan menyebabkan gangguan kesehatan seperti diare (Suara Merdeka,2003) 
Kadar zat organik dipengaruhi oleh lama penyimpanan sebagaimana yang dijelaskan oleh penelitian Ana Hidayati (2010)

Adanya pertumbuhan mikroorganisme dalam air minum yang dapat meningkatkan kadar zat organik dimungkinkan disebabkan oleh suhu air, $\mathrm{pH}$ air, proses pengolahan atau alat pengolah tidak berfungsi dengan baik dan proses pembersihan atau pencucian galon yang kurang baik.

Bakteri dapat tumbuh subur pada suasana aerob dan suhu psikorofilik, mesofilik maupun termofilik. Hal ini sesuai dengan penelitian yang dilakukan oleh Rahayu (2008) tentang deteksi adanya bakteri pada air minum dalam kemasan galon telah ditemukan adanya beberapa bakteri didalam air minum dan terjadi pertambahan jumlah bakteri akibat proses perkembangbiakan bakteri dari bakteri awal.

$\mathrm{pH}$ merupakan salah satu faktor yang sangat penting mengingat $\mathrm{pH}$ dapat mempengaruhi pertumbuhan mikroba dalam air. Sebagian mikroba di dalam air akan tumbuh dengan baik pada $\mathrm{pH}$ 6,0 - 8,0 selain itu $\mathrm{pH}$ juga dapat menyebabkan perubahan kimiawi dalam air. Apabila pH lebih kecil dari 6,5 dan lebih besar dari 9,2 maka akan dapat mengakibatkan beberapa senyawa kimia berubah menjadi racun yang dapat menganggu kesehatan manusia.

Pada prinsipnya pengolahan air minum pada setiap produsen adalah sama yaitu untuk menghilangkan bau, warna, rasa, bahan kimia berbahaya serta menghilangkan mikroorganisme. Pada dasarnya pengolahan air minum diproses melalui 3 (tiga) tahap yaitu penyaringan, desinfeksi dan pengisian.

Penyaringan dimaksudkan untuk menghilangkan bau dan kotoran, desinfeksi bertujuan untuk menghilangkan sebagian besar mikroorganisme dan membunuh bakteri pathogen dalam air, sedangkan pengisian adalah tahap akhir pengemasan air yang telah diproses.

Seharusnya alat dan perlengkapan yang dipergunakan seperti mikro filter dan alat sterilisasi masih dalam masa pakai (tidak kadaluwarsa) (Direktorat Penyehatan Lingkungan, 2006).

Proses pengolahan atau alat pengolah yang sudah tidak berfungsi dengan baik tidak dapat menghilangkan mikroorganisme, sehingga mikroorganisme yang ada dalam air minum dimungkinkan dapat mengalami pertumbuhan.

Proses pengolahan air minum yang dilakukan minimal sebagai berikut saringan berasal dari pasir, saringan karbon aktif, microfilter, desinfeksi menggunakan ozon, sinar ultraviolet maupun reverse osmosis (Nusa Idaman S,2011).

3. Lama Penyimpanan 4 Hari
Rata-rata kadar zat organik air minum baik pada kondisi DAM MS maupun DAM TMS dengan lama penyimpanan 4 hari cenderung menurun dari penyimpanan 2 hari.

Hal tersebut diindikasi disebabkan oleh adanya oksidasi atau dekomposisi (penguraian) zat organik oleh mikroorganisme.

G.Alaerts dalam Sri Sumestri S (1987) menyatakan bahwa oksigen dibutuhkan oleh bakteri atau mikroorganisme untuk menguraikan (mengoksidasikan) hampir semua zat organik yang terlarut dan sebagian zat-zat organik yang tersuspensi dalam air. Selain itu penguraian zat organik merupakan peristiwa alamiah apabila air yang telah tercemar zat organik bakteri dapat menghabiskan oksigen terlarut dalam air selama proses oksidasi yang dapat menimbulkan bau busuk pada air tersebut.

Selain itu, zat organik dapat disisihkan secara biologi, dengan beberapa variabel yang berpengaruh antara lain jumlah oksigen terlarut (DO), waktu kontak, senyawa pengganggu (inhibitor), jenis dan jumlah mikroorganisme pengurai (Bitton, 1994).

Adanya oksigen menyebabkan proses oksidasi aerob dapat berlangsung,bahan-bahan organik akan dirubah menjadi produk -produk akhir yang relative stabil dan sederhanya yang sisanya akan disintesis menjadi mikroba baru.

Proses pengolahan air yang mengandung polutan senyawa organik, teknologi yang digunakan sebagian besar menggunakan aktifitas mikroorganisme untuk menguraikan senyaw polutan organik tersebut. Proses pengolahan secara biologis dapat dilakukan pada kondisi aerobik (dengan udara), kondisi anaerobik (tanpa udara) atau kombinasi aerobik dan anaerobik. Pengolahan air yang mengandung zat organik dapat dilakukan secara biologis, pada prinsipnya proses biologis akan mengubah bahan- bahan pencemar yang berbentuk koloid atau terlarut yang ada di dalam air baku menjadi bentuk lain dalam bentuk gas, maupun jaringan sel yang dapat dipisahkan dengan proses fisis seperti pengendapan. Seperti yang dijelaskan Miwa (1991).

Kadar zat organik pada DAM MS setelah penyimpanan 4 hari dibanding penyimpanan 0 hari mengalami kenaikan sedangkan pada DAM TMS setelah penyimpanan 4 hari dibanding penyimpanan 0 hari mengalami penurunan. Hal tersebut dimungkinkan disebabkan oleh beberapa hal seperti perbedaan sumber air baku pada DAM MS dan DAM TMS sehingga kadar zat organiknya juga berbeda, saat dilakukan penelitian terdapat adanya kesalahan dalam penentuan kondisi DAM, proses pengolahan atau teknologi pengolahan yang dilakukan, adanya oksigen yang lebih banyak masuk saat pengambilan sampel hari ke-4 pada air minum 
DAM TMS sehingga proses oksidasi (penguraian) berlangsung dan kadar zat organik menjadi lebih rendah selain itu dimungkinkan adanya pengaruh mikroorganisme, dimungkinkan mikroorganisme pada DAM MS lebih rendah dibandingkan DAM TMS sehingga pada hari 0 kadar zat organik relative rendah kemudian setelah penyimpanan 4 hari relative tinggi dibandingkan hari ke 0 yang dimungkinkan disebabkan oleh mikroorganisme yang ada tidak dapat mengoksidasi semua zat organik dalam air minum.

Hasil Pemeriksaan rata-rata Kadar Zat Organik pada kondisi DAM MS sebesar 16,08 $\mathrm{mg} / \mathrm{l} \mathrm{KMnO}_{4}$, sedangkan pada kondisi DAM TMS sebesar 15,80 mg/l $\mathrm{KMnO}_{4}$. Maka ratarata kadar zat organik pada DAM MS sedikit lebih tinggi dibandingkan pada DAM TMS seperti yang ditunjukan oleh Tabel 3.1.

Hal ini dapat disebabkan karena ada beberapa faktor yang mempengaruhi kualitas air minum yang dihasilkan depot seperti air baku, kebersihan penjamah atau operator , penanganan terhadap wadah pembeli dan kondisi Depot. (Afif dkk, 2015)

Bahan baku utama yang digunakan adalah air yang diambil dari sumber yang terjamin kualitasnya, untuk itu beberapa hal yang harus dilakukan untuk menjamin mutu air baku yaitu sumber air baku harus terlindung dari cemaran kimia dan mikrobiologi yang bersifat merusak atau mengganggu kesehatan. Selain itu air baku diperiksa secara berkala terhadap pemeriksaan organoleptik(bau,rasa, warna), fisika, kimia dan mikrobiologi (Kepmen Perindustrian \& Perdagangan No 651/2004).

Sumber air baku yang digunakan secara alami telah mengandung zat organik. Air baku pada pengolahan DAM MS berasal dari PDAM. Menurut Thedy Susanto (2010), air olahan PDAM memiliki kualitas yang kurang baik yang dapat disebabkan karena kualitas air baku yang buruk, operasional dan maintenance yang kurang baik serta kerusakan pipa jaringan PDAM. Kemudian ditegaskan pada hasil penelitian Tri Tugaswati (1987) penyimpangan kadar Zat Organik dalam air minum diperkirakan akibat kontaminasi lingkungan pada jaringan pipa distribusi PDAM.

Sedangkan air baku untuk pengolahan DAM TMS berasal dari mata air pegunungan . Dimana mata air pegunungan sudah terjamin kualitasnya dan sudah memenuhi persyaratan air minum ( Dikri dkk, 2012).

Mata air merupakan salah satu sumber air bersih yang baik bila dipakai sebagai air baku, karena berasal dari dalam tanah yang muncul ke permukaan tanah akibat tekanan, sehingga belum terkontaminasi oleh lingkungan sekitar. Apabila mata air berlokasi di daerah terbuka, dimungkinkan akan terkontaminasi oleh lingkungan sekitar (Rahayu,2013)

Seperti yang telah dijelaskan oleh Rahayu (2013), mata air yang digunakan oleh DAM TMS dimungkinkan telah tercemar oleh lingkungan sekitar karena berada di dekat fasilitas MCK (mandi,cuci,kakus).

Penyimpanan air baku yang terlalu lama dapat berpengaruh terhadap kualitas air minum yaitu semakin bakteri yang akan tumbuh, meningkatnya kebutuhan oksigen untuk mengoksidasi bahan kimia secara kimiawi dan mengoksidasi bahan organik secara biologis serta menurunnya $\mathrm{pH}$, TDS, kesadahan dan kandungan ion $\mathrm{Fe}$ sebagaimana yang dikemukakan oleh Fitri (2010). Ini sesuai dengan pendapat Athena (2004) yang menyatakan bahwa penyimpanan air baku yang terlalu lama (lebih dari 3 hari) dapat bepengaruh terhadap kualitas air minum yaitu menimbulkan pertumbuhan mikroorganisme. Dimana pertumbuhan mikroorganisme dapat meningkatkan kadar zat organik dalam air.

Proses pengolahan air minum yang dapat mengurangi zat organik adalah proses penyaringan menggunakan karbon aktif dan ozon. Proses penyaringan yang dilakukan pada Depot Air Minum (DAM) salah satunya adalah filter karbon aktif. Filter karbon aktif biasanya berasal dari batu bara atau batok kelapa yang berfungsi sebagai untuk menghilangkan polutan mikro seperti menyerap bau, warna, rasa, sisa khlor dan bahan organik serta logam berat dalam air. Dalam saringan karbon aktif ini terjadi proses adsorbs yaitu penyerapan zat-zat yang akan dihilangkan oleh permukaan arang aktif. Apabila seluruh permukaan karbon/ arang aktif sudah jenuh atau sudah tidak mampu lagi menyerap maka proses penyerapan akan berhenti dan pada saat itu karbon aktif harus diganti dengan karbon aktif yang baru (Nusa Idaman Said,2011).

Ozon merupakan senyawa yang mampu membunuh bakteri dan mempunyai daya oksidasi yang kuat. Oksidator ini sering digunakan untuk desinfeksi utama untuk membunuh atau mengaktivasi mikroorganisme pathogen dan mengoksidasi zat besi dan mangan, senyawa penyebab rasa dan bau, warna, zat organik, detergen, fenol serta bahan organik lainnya (Sutrisno,2006)

Apabila kedua proses pengolahan ini tidak berfungsi dengan baik atau sudah tidak efisien dimungkinkan kadar zat organik dalam air minum pun tidak dapat dihilangkan atau kadar zat organiknya masih tinggi. Namun selain dari 2 proses pengolahan tersebut juga proses pengolahan lain seperti saringan pasir, mikrofilter dan desinfeksi juga berpengaruh terhadap pertumbuhan mikroorganisme yang 
dapat meningkatkan kadar zat organik dalam air minum.

Proses sudah dilakukan dengan baik namun dalam penanganan wadah pembeli dalam proses pembersihan atau pencucian gallon kurang bersih sehingga dimungkinkan adanya kontaminasi.

Penanganan terhadap wadah pembeli juga mempengaruhi kualitas air minum yang dihasilkan. Walaupun air yang dihasilkan berkualitas, tapi jika tidak ada perhatian lebih terhadap wadah galon sebagai tempat untuk mengisikan maka akan memungkinkan terjadi kontaminasi terhadap air yang dihasilkan (Depkes,2003).

Proses pembersihan atau pencucian galon kurang bersih sehingga dimungkinkan adanya kontaminasi. DAM MS dalam penanganan terhadap wadah pembeli seperti yang umum digunakan pada depot-depot yang lain dengan menyikat dan membilas dengan air produk setelah itu langsung diisi kembali. Sedangkan pada DAM TMS dalam penanganan terhadap wadah pembeli tidak memenuhi syarat karena dalam penanganan wadah pembeli sama sekali tidak dilakukan pencucian maupun pembilasan sebelum diisi kembali.

Menurut Afif dkk (2015) penanganan terhadap wadah konsumen yang baik dilakukan dengan pencucian menggunakan berbagai jenis detergen khusus yang disbut dengan sara pangan (food grade) dan air bersih dengan suhu berkisar $60-85^{\circ} \mathrm{C}$

Karyawan yang berhubungan dengan produksi harus dalam keadaan sehat, bebas dari luka, penyakit kulit atau hal lain yang diduga dapat mengakibatkan pencemaran terhadap air minum. Karyawan bagian produksi diharuskan menggunakan pakaian kerja, tutup kepala dan sepatu yang sesuai.

Pengetahuan operator depot air minum tentang kebersihan tentu juga akan mempengaruhi kualitas air yang dihasilkan. Hanya sebagian kecil penjual sekaligus operator Depot Air Minum yang mengerti betul arti kebersihan baik pada tempat proses air, lingkungan sekitar, pakaian yang dikenakan dan kebersihan diri sendiri (Pitoyo,2005).

Kondisi Fisik Depot, dalam hal di atas sudah baik namun kondisi fisik depot (atap, lantai, dinding dll) masih tidak memenuhi syarat juga dapat memungkinkan adanya kontaminasi.

\section{Bivariate \\ Uji Statistik}

Hasil analisis bivariate mengenai pengaruh lama penyimpanan dan kondisi DAM terhadap kadar zat organik air minum menggunakan analisis Anova Factorial .
Perbedaan kadar zat organik dengan lama penyimpanan (0 hari, 2 hari dan 4 hari)

Tabel 3.2 Hasil Uji Lanjut Perbedaan Kadar Zat Organik Air Minum Dengan Lama Penyimpanan (0 Hari,2 Hari dan 4 Hari)

\begin{tabular}{|c|c|c|c|}
\hline No & Variabel & Beda Mean & $\mathbf{P}$ \\
\hline 1. & 0 Hari dengan 2 Hari & - 10.456 & 0.000 \\
\hline 2. & 0 Hari dengan 4 Hari & 0.667 & 0.423 \\
\hline 3. & 2 Hari dengan 0 Hari & 10.456 & 0.000 \\
\hline 4. & 2 Hari dengan 4 Hari & 9.789 & 0.000 \\
\hline 5. & 4 Hari dengan 0 Hari & 0.667 & 0.423 \\
\hline 6. & 4 Hari dengan 2 Hari & 9.789 & 0.000 \\
\hline
\end{tabular}

Hasil analisis uji Anova Factorial menunjukan lama penyimpanan 2 hari menunjukan nilai $\mathrm{p}<0,05$ berarti setelah lama penyimpanan 2 hari meningkatkan kadar zat organik air minum. Dengan demikian lama penyimpanan yang paling berpengaruh yaitu setelah lama penyimpanan 2 hari. Kadar zat organik dengan lama penyimpanan 2 hari berbeda dengan lama penyimpanan 0 dan 4 hari, sedangkan kadar zat organik dengan lama penyimpanan 0 hari tidak ada beda dengan lama penyimpanan 4 hari. Berarti setelah lama penyimpanan 0 Hari ke 2 Hari terdapat kenaikan kemudian setelah penyimpanan 4 Hari mengalami penurunan.

Hasil statistic menggunakan SPSS 17.0 dengan menggunakan Uji Anova Factorial hasil nilai p (Sig.) $0,000<\alpha(0,05)$ maka Ho ditolak yang berarti ada perbedaan kadar zat organik air minum dengan lama penyimpanan (0,2 dan 4 hari).

a. 0 hari dengan 2 hari

Kadar zat organik antara lama penyimpanan 0 hari dengan 2 hari dengan nilai p (sig.) 0,000 < 0,05 maka Ho ditolak yang berarti ada perbedaan. Ada perbedaan ini disebabkan karena rata-rata kadar zat organik mengalami kenaikan sebesar $61,53 \%$.

Kenaikan kadar zat organik air minum dimungkinkan disebabkan oleh adanya perkembangbiakkan mikroorganisme (Ana Hidayati,2010). Selain itu adanya kontaminasi zat organik dari lingkungan dan adanya kesalahan dalam pengambilan sampel sehinggan kadar zat organik dalam air minum yang diperiksa meningkat.

b. 2 hari dengan 4 hari

Kadar zat organik antara lama penyimpanan 2 hari dengan 4 hari dengan nilai p (sig.) 0,000 < 0,05 maka Ho ditolak yang berarti ada perbedaan. Ada perbedaan ini disebabkan karena rata-rata kadar zat organik mengalami penurunan sebesar 57,69\%.

Hal tersebut diindikasi disebabkan oleh adanya penguraian atau dekomposisi zat organik oleh mikroorganisme (Sri Sumestri,1987).

c. 0 hari dengan 4 hari 
Kadar zat organik antara lama penyimpanan 0 hari dengan 4 hari dengan nilai p (sig.) 0,423< 0,05 maka Ho diterima yang berarti tidak ada perbedaan yang signifikan antara kadar zat organik 0 hari dengan 4 hari. Hal tersebut disebabkan karena setelah penyimpanan 4 hari mengalami penurunan dan kadar zat organik relative sama.

Adanya perbedaan kadar zat organik tersebut dimungkinkan dapat disebabkan oleh beberapa hal seperti suhu air, $\mathrm{pH}$ air, kelembaban ruang penyimpanan dan adanya perkembangbiakan mikroorganisme. Selain itu dimungkinkan adanya kesalahan dalam pengambilan sampel dan pengiriman sampel sehingga air minum yang diperiksa terkontaminasi oleh zat organik yang lebih banyak.

Hasil penelitian ini sesuai dengan hasil penelitian Ana Hidayati (2010) menyatakan ada pengaruh lama penyimpanan terhadap kadar zat organik air minum isi ulang.

Perbedaan kadar zat organik pada kondisi Depot Air Minum MS (Memenuhi Syarat mikrobiologis dan hygiene sanitasi) dan Depot Air Minum TMS (Tidak Memenuhi Syarat mikrobiologis dan hygiene sanitasi)

Hasil analisis bivariate mengenai pengaruh kondisi DAM terhadap kadar zat porganik air minum menggunakan analisis Anova Factorial menunjukkan bahwa tidak ada perbedaan kadar zat organik air minum pada kondisi DAM yang memenuhi syarat maupun kondisi DAM yang tidak memenuhi syarat yang ditunjukan pada Tabel 3.3 berikut ini:

Tabel 3.3 Perbedaan Kadar Zat Organik Air minum pada Kondisi DAM

\begin{tabular}{|c|c|c|}
\hline Variabel & Beda Mean & $\mathbf{P}$ \\
\hline Memenuhi Syarat dengan & 0.289 & 0.727 \\
\hline Tidak Memenuhi Syarat & & \\
\hline $\begin{array}{l}\text { Tidak memenuhi syarat } \\
\text { dengan memenuhi syarat }\end{array}$ & $\begin{array}{r}-\quad 0.2 \\
89\end{array}$ & 0.727 \\
\hline
\end{tabular}

Hasil statistik menggunakan Uji lanjut Anova Factorial hasil nilai p (sig.) $0,727<\alpha(0,05)$ maka Ho diterima yang berarti tidak ada perbedaan kadar zat organik air minum pada kondisi DAM yang Memenuhi Syarat dan Tidak Memenuhi Syarat.

Tidak adanya perbedaan kadar zat organik yang signifikan tersebut dimungkinkan terjadi karena beberapa faktor seperti beberapa hal yang ada di Kondisi DAM MS dan DAM TMS sama-sama dapat menyebabkan timbulnya kadar zat organik atau mempengaruhi kualitas air seperti yang dijelaskan oleh Afif,dkk (2015). Beberapa hal tersebut yaitu sumber air baku, proses pengolahan, proses pembersihan atau pencucian galon, personal hygiene karyawan dan kondisi depot air minum.
Selain karena kondisi Depot Air Minum tersebut, dimungkinkan kadar zat organik air minum pada Kondisi DAM MS dan TMS tidak ada perbedaan karena adanya kesalahan penelitian dalam menentukan kategorisasi kondisi Depot Air Minum tersebut dan kesalahan dalam pengambilan sampel dan pengiriman sampel sehingga kadar zat organik baik pada kondisi DAM yang Memenuhi Syarat secara mikrobiologis dan hygiene sanitasi serta Kondisi DAM yang Tidak Memenuhi Syarat secara mikrobiologis dan hygiene sanitasi kadarnya relative sama atau tidak ada perbedaan yang signifikan.

\section{SIMPULAN DAN SARAN}

\section{Simpulan}

Rata-rata kadar zat organik air minum yang disimpan 0 sampai 4 hari pada kondisi DAM yang berbeda berturut-turut adalah DAM MS $=7,96$ $\mathrm{mg} / \mathrm{l} ; 28,1 \mathrm{mg} / \mathrm{l} ; 12,2 \mathrm{mg} / \mathrm{l}$. DAM TMS $=12,8$ $\mathrm{mg} / \mathrm{l} ; 24,03 \mathrm{mg} / \mathrm{l} ; 10,5 \mathrm{mg} / \mathrm{l}$.

Ada perbedaan kadar zat organik dengan lama penyimpanan ( 0 hari, 2 hari dan 4 hari) dengan nilai p $0,000<0,05$ maka Ho ditolak.

Tidak ada perbedaan kadar zat organik air minum pada kondisi DAM Memenuhi Syarat dan DAM Tidak Memenuhi Syarat dengan nilai p 0,727 $>$ 0,05 maka Ho diterima.

\section{Saran}

Disarankan untuk masyarakat sebaiknya mengkonsumsi air minum sebelum 2x24 jam sejak pengisian, pengusaha DAM selalu menjaga kualitas air minum yang dijual dan perlu dilakukan penelitian dengan penyimpanan yang lebih lama dan penelitian lanjutan untuk parameter mikroorganisme berdasarkan jenis teknologi pengolahan depot air minum (DAM).

\section{DAFTAR PUSTAKA}

American Public Health Association, 1985, Standars Methods for The Examination of Water and Waste Water. America : Managing Editor

Ana Hidayati, 2010, Pengaruh Lama Waktu Simpan pada Suhu Ruang $\left(27-29^{\circ} \mathrm{C}\right)$ Terhadap Kadar Zat Organik pada Air Minum Isi Ulang. Skripsi. Fakultas Ilmu Keperawatan dan Kesehatan, Universitas Muhammadiyah Semarang : Semarang

Arikunto S, 2013, Prosedur Penelitian Suatu Pendekatan Praktek, Jakarta: Rineka Cipta

Athena.,dkk, 2004, kandungan bekteri total coli dan eschericia coli/Fecal coli air minum dari depot air minum isi ulang di Jakarta, Tangerang dan Bekasi. Buletin Penelitian Keehatan Vol.32 No.4. 
Depkes RI, 2006, Pedoman Pelaksanaan Penyelenggaraan Hygiene Sanitasi Depot Air Minum. Direktorat Penyehatan Lingkungan Direktorat Jenderal Pengendalian Penyakit dan Penyehatan Lingkungan Depkes RI : Jakarta

Effendi Hefni, 2003, TELAAH KUALITAS AIR Bagi Pengelolaan Sumber Daya dan Lingkungan Perairan, Yogyakarta : Kanisius

Herwanti , 2013, “Studi Kualitas Bakteriologis Depot Air Minum Isi Ulang (DAMIU) di Wilayah Kerja Puskesmas Purwokerto Selatan Kabupaten Banyumas Tahun 2013”, KTI, Purwokerto : JKL Purwokerto

Idaman S. Nusa, 2008, Teknologi Pengolahan Air Minum “Teori dan Pengalaman Praktis”, Jakarta : Pusat Teknologi Lingkungan BPPT

Idaman S. Nusa, 2011, Teknologi Pengolahan Air Minum “Teori dan Pengalaman Praktis”, Jakarta : Pusat Teknologi Lingkungan BPPT

Lestari. D, 2014, "Sanitasi dan Kualitas Bakteriologis Air Minum Isi Ulang (DAMIU) di Kecamatan Kalimanah Kabupaten Purbalingga tahun 2014”, KTI, Purwokerto : JKL Purwokerto

Notoatmodjo. S, 2007, Kesehatan Masyarakat, PT. Jakarta : Rineka Cipta

Metcalf and Eddy, 2004, “ Waste Water Engineering Treatment Disposal Reuse”, Fourth Edition, New York.

Rabiatul Al Adawiyah, 2014, Gambaran Jumlah Bakteri Escherichia coli pada Air Minum Isi Ulang (AMIU) Sumber Depot Berdasarkan Lama Penggunaan pada Penghuni Kos Smart Center Kota Gorontalo. Skripsi. Jurusan Kesehatan Masyarakat, Fakultas Ilmu - ilmu Kesehatan dan Keolahragaan Universitas Negeri Gorontalo : Gorontalo.
Rahayu,dkk, 2013, Faktor Resiko Pencemaran Mikrobiologi pada Air Minum Isi Ulang di Kabupaten Tegal, Indonesia : Jurusan Kesehatan Lingkungan Indonesia

Ramlan. D \& Marlyn, 2013, Petunjuk Praktis Penulisan Penelitian Eksplanatif, Purwokerto : UPT Percetakan dan Penerbitan Universitas Jenderal Soedirman

Santjaka A, 2011, Statistik untuk Penelitian Kesehatan 1, Nuha Medika : Yogyakarta

Santjaka A, 2015, Aplikasi SPSS untuk Analisis Data Penelitian Kesehatan, Nuha Medika : Yogyakarta

Sastrawijaya, A. Tresna, 2000, Pencemaran Lingkungan, Jakarta : Rineka Cipta

Slamet, J.S, 2004, Kesehatan Lingkungan, Yogyakarta : Gadjah Mada University Press.

SNI No 01-3553, 1996, Air Minum Dalam Kemasan, Jakarta

Soedarto, 2013, Lingkungan dan Kesehatan , Jakarta : Sagung Seto

Sumestri, Sri dkk, 2006, Metoda Penelitian Air, Surabaya : Usaha Nasional

Suriawiria, U. 2008. Mikrobiologi Air dan Dasar dasar Pengolahan Buangan secara Biologis. Bandung : Angkasa.

Sutrisno,T. 2006. Teknologi Penyediaan Air Bersih, Jakarta : PT. Asdi Mahasatya.

Tugaswati, Tri, 1987, Evaluasi kualitasi air minu PAM DKI Jaka rta, Jakarta

Totok Sutrisno. C, 2010, Teknologi Penyediaan Air Bersih, Jakarta : Rineka Cipta

Winarno, F.G.,1993, Air untuk Industri Pangan, Jakarta : PT. Gramedia. 